\title{
MEDIASI DALAM PENYELESAIAN SENGKETA PERDATA DI PENGADILAN NEGERI KELAS I B BLITAR
}

\author{
Christina Simanullang', Anik Iftitah ${ }^{2}$ \\ ${ }^{1}$ Hakim Pengadilan Negeri Blitar, \\ E-mail: simanullang@yahoo.co.id \\ ${ }^{2}$ Fakultas Hukum Universitas Islam Balitar, \\ E-mail: geest_willdaad@yahoo.com
}

\begin{abstract}
ABSTRAKSI
Mahkamah Agung Republik Indonesia dalam rangka reformasi birokrasi, menjadikan mediasi sebagai salah satu elemen pendukung untuk meningkatkan akses masyarakat terhadap keadilan. Cita tersebut belum terimplementasi secara optimal di Pengadilan Negeri Kelas I B Blitar, karena pengguna mediasi yang minim. Penelitian hukum empiris di Pengadilan Negeri Kelas I B Blitar dengan teori sistem hukum menunjukkan bahwa pelaksanaan prosedur mediasi di Pengadilan Negeri Kelas I B Blitar sesuai dengan PERMA Nomor 1 Tahun 2016 tentang Prosedur Mediasi di Pengadilan, perkara yang berhasil mencapai perdamaian melalui mediasi di Pengadilan Negeri Kelas I B Blitar sangat minim, dipengaruhi oleh faktor minimnya jumlah hakim bersertifikat mediator yang hanya berjumlah 1 (satu), rendahnya kemauan untuk berdamai dari para pihak, kesulitan mengakses informasi penyelenggaraan sertifikasi mediator, belum jelasnya kriteria keberhasilan mediasi, ketidakjelasan insentif hakim dan non hakim yang berhasil sebagai mediator, dan budaya hukum para pihak berperkara yang masih memilih jalur litigasi.
\end{abstract}

Kata kunci: Mediasi, Sengketa Perdata, Pengadilan Negeri

\section{PENDAHULUAN}

\section{Latar Belakang}

Mahkamah Agung Republik Indonesia dalam rangka reformasi birokrasi yang berorientasi pada visi terwujudnya badan Peradilan Indonesia yang agung, menjadikan mediasi sebagai salah satu elemen pendukung untuk meningkatkan akses masyarakat terhadap keadilan sekaligus implementasi asas penyelenggaraan peradilan yang sederhana, cepat dan berbiaya ringan.

Mediasi berasal dari bahasa Inggris "mediation"atau penengahan yaitu penyelesaian sengketa yang melibatkan pihak ketiga sebagai penengah atau penyelesaian sengketa secara menengah. Sedangkan secara etimologi, istilah mediasi berasal dari bahasa Latin "mediare" yang berarti berada di tengah. Makna ini menunjuk pada peran yang ditampilkan pihak ketiga sebagai mediator harus berada pada posisi netral dan tidak memihak dalam menyelesaikan sengketa. Mediator harus mampu menjaga kepentingan para pihak yang bersengketa secara adil dan sama, sehingga menumbuhkan kepercayaan (trust) dari para pihak yang bersengketa. ${ }^{1}$

Prosedur mediasi di pengadilan menjadi bagian hukum acara perdata yang dapat memperkuat dan mengoptimalkan fungsi lembaga peradilan dalam penyelesaian sengketa. Berdasarkan hal tersebut Mahkamah Agung berpendapat bahwa PERMA Nomor 01 Tahun 2008 tentang Prosedur Mediasi di Pengadilan belum optimal memenuhi kebutuhan pelaksanaan Mediasi yang lebih berdayaguna dan mampu meningkatkan keberhasilan

\footnotetext{
1 Syahrial Abbas, Mediasi dalam Hukum Syariah, Hukum Adat dan Hukum Nasional, Jakarta: Kencana 2011, hal. 1-2.
} 
Mediasi di Pengadilan sehingga berdasarkan pertimbangan tersebut Mahkamah Agung mengeluarkan PERMA Nomor 1 Tahun 2016 tentang Prosedur Mediasi di Pengadilan. ${ }^{2}$

Prinsip mediasi adalah cara penyelesaian sengketa di luar pengadilan melalui perundingan yang melibatkan pihak ketiga yang bersifat netral (non intervensi) dan tidak berpihak (imparsial) serta diterima kehadirannya oleh pihak-pihak yang bersengketa. ${ }^{3}$ Pihak ketiga disebut mediator atau penengah, mempunyai tugas membantu pihak-pihak yang bersengketa dalam menyelesaikan masalahnya, tetapi tidak mempunyai kewenangan untuk mengambil keputusan. ${ }^{4}$ Mediator memegang peranan yang sangat penting dalam menyelesaikan sengketa antara para pihak, yang mana sebagaimana ketentuan Pasal 16 PERMA Nomor 1 Tahun 2016 bahwa Ketua Pengadilan wajib menyampaikan kinerja Hakim atau Pegawai Pengadilan yang berhasil menyelesaikan perkara melalui mediasi kepada Ketua Pengadilan Tinggi dan Mahkamah Agung5, namun pengguna mediasi atau animo di Pengadilan Negeri Kelas I B Blitar masih kurang.

Pengadilan Negeri Kelas I B Blitar merupakan Pengadilan Negeri di Wilayah Hukum Pengadilan Tinggi Surabaya yang mempunyai sarana dan prasarana seperti ruang khusus untuk mediasi dan terdapat hakim yang telah bersertifikat Mahkamah Agung Republik Indonesia yang menjalankan fungsi sebagai mediator hakim. Keberhasilan mediasi di Pengadilan Negeri Kelas I B Blitar ini pada sengketa atau perkara perdata tahun 2015 yang masuk ke Pengadilan Negeri Kelas I B Blitar hanya sebanyak 3 (tiga) kasus dari 111 (seratus sebelas) perkara gugatan. Tahun 2016 perkara gugatan yang masuk ke Pengadilan Negeri Kelas I B Blitar sampai dengan tanggal 14 Juni 2016 ada sebanyak 68 (enam puluh delapan) perkara gugatan sedangkan yang berhasil di mediasi hanya sebanyak 1 (satu) kasus. Atas persolan yuridis empiris tersebut di atas, upaya mediasi dalam penyelesaian sengketa perdata di Pengadilan Negeri Kelas I B Blitar sangat penting untuk diteliti.

\section{RUMUSAN MASALAH}

1. Bagaimana prosedur mediasi di Pengadilan Negeri Kelas I B Blitar?

2. Bagaimana peranan mediasi dalam menyelesaikan sengketa perdata di Pengadilan Negeri Kelas I B Blitar?

3. Apakah faktor-faktor yang mempengaruhi pelaksanaan mediasi di Pengadilan Negeri Kelas I B Blitar?

\section{METODE PENELITIAN}

Penelitian dilaksanakan di Pengadilan Negeri Kelas I B Blitar. Populasi dan sampel dalam penelitian ini adalah pihak-pihak yang terlibat langsung dengan penerapan mediasi itu sendiri yang didalamnya terdapat: Para pihak dalam perkara perdata, hakim yang menangani perkara, mediator, kuasa hukum para pihak, pegawai atau pejabat Pengadilan Negeri Kelas I B Blitar yang berkaitan dengan dokumen atau berkas perkara perdata.

\footnotetext{
2 Konsideran Peraturan Mahkamah Agung No.1 Tahun 2016.

3 Bambang Sutiyoso, Hukum Arbitrase dan Alternatif Penyelesaian sengketa, Yogyakarta: Gama Media, 2008, hal. 58 .

4 Ibid.

${ }^{5}$ Ketentuan Pasal 16 Peraturan Mahkamah Agung No.1 Tahun 2016.
} 
Peneliti menggunakan data primer yaitu data yang diperoleh dari penelitian lapangan berupa keterangan dan penjelasan yang diberikan para narasumber yang diperoleh melalui wawancara yang diperlukan dalam penelitian dan yang telah disample oleh peneliti, dan data sekunder yaitu data tambahan yang diperoleh dari berbagai sumber hukum yang berhubungan dengan permasalahan yang diteliti baik dari Peraturan perundang-undangan, Peraturan Mahkamah Agung Republik Indonesia maupun dari Putusan Pengadilan Negeri Blitar disamping itu buku, literature maupun artikel-artikel yang terkait materi penelitian dapat dijadikan sebagai sumber data dalam penelitian ini.

Tehnik pengumpulan data dalam penelitian ini menggunakan studi dokumen dan wawancara. ${ }^{6}$ Studi dokumen merupakan suatu alat pengumpulan data yang dilakukan melalui data tertulis dengan mempergunakan content analysis. ${ }^{7}$ Sebelum melakukan pencarian data kelapangan, terlebih dahulu melaksanakan studi pustaka untuk memperoleh data sekunder yang telah lebih dahulu ada. Untuk mendapatkan data primer dilakukan dengan cara mewawancarai informan yang terdiri dari hakim, mediator hakim, serta para pihak yang berperkara, advokat yang menangani perkara perdata baik yang berhasil diselesaikan melalui mediasi di Pengadilan Negeri Kelas I B Blitar maupun yang gagal di mediasi di Pengadilan Negeri Kelas I B Blitar dan untuk memperoleh laporan tahunan didapat dari Panitera Muda Hukum dan Panitera Muda Perdata yang menyediakan informasi mengenai jumlah perkara yang masuk ke pengadilan.

Pengolahan data dan bahan hukum dilakukan secara kualitatif untuk mengetahui Penerapan PERMA Nomor 01 Tahun 2008 tentang Mediasi Dalam Penanganan Perkara Perdata di Pengadilan Negeri Kelas I B Blitar sehingga dapat membantu sebagai dasar acuan dan pertimbangan hukum yang berguna dalam penyusunan peraturan perundangan mediasi di pengadilan secara tepat.

\footnotetext{
${ }^{6}$ Soerjono Soekanto, Wawancara sebagai salah satu teknik dalam penelitian bertujuan untuk mengumpulkan keterangan atau data, Ringkasan Metodologi Penelitian Hukum Empiris, Jakarta: Indhilco, 1990, hal. 115.

${ }^{7}$ Soerjono Soekanto, Op.Cit. hal.21.
} 


\section{PROSEDUR MEDIASI DI PENGADILAN NEGERI KELAS I B BLITAR}

\section{Pendaftaran Gugatan}

Proses mediasi pada awalnya sama seperti proses berperkara biasa, di mana Penggugat mendaftarkan gugatannya ke Kepaniteraan Pengadilan Negeri Kelas I B Blitar. Kepaniteraan Pengadilan Negeri Kelas I B Blitar melalui bagian yang khusus untuk menerima gugatan, mendaftarkan/ mencatat nomor gugatan ke dalam suatu buku register, setelah terlebih dahulu menerima uang pendaftaran gugatan dari pihak yang mendaftarkan gugatan. ${ }^{8}$

Kemudian pihak administrasi Pengadilan Negeri Kelas I B Blitar akan meneruskan berkas perkara kepada Ketua Pengadilan Negeri Kelas I B Blitar. Setelah Ketua Pengadilan Negeri Kelas I B Blitar menerima dan membaca berkas perkara, selanjutnya Ketua Pengadilan akan membuat penetapan Majelis Hakim Pemeriksa Perkara yang akan menangani perkara tersebut dan setelah itu Ketua Pengadilan Negeri Kelas I B Blitar akan menyerahkan berkas perkara kepada Hakim Pemeriksa Perkara yang telah ditunjuk. ${ }^{9}$

Hakim Pemeriksa Perkara yang telah ditunjuk oleh Ketua Pengadilan Negeri mempelajari berkas perkara dan menentukan suatu hari persidangan guna memulai proses berperkara. Melalui Juru Sita atau Juru Sita Pengganti, Hakim Pemeriksa Perkara memanggil para pihak yang berperkara untuk hadir di Pengadilan Negeri Kelas I B Blitar pada hari yang sudah ditetapkan dalam surat panggilan atau risalah panggilan.

Pada hari sidang yang telah ditentukan, para pihak baik pihak Penggugat dan pihak Tergugat yang dipanggil menghadap kepada Panitera Pengganti (PP) Pengadilan Negeri Kelas I B Blitar untuk melaporkan bahwa mereka telah hadir dan siap untuk mengikuti persidangan. Panitera Pengganti (PP) melapor kepada Hakim Pemeriksa Perkara, agar persidangan segera dimulai pada suatu ruang sidang yang telah ditentukan. Setelah Hakim Pemeriksa Perkara dan para pihak memasuki ruang persidangan, Hakim Pemeriksa Perkara membuka persidangan dengan membacakan nomor gugatan dan nama-nama para pihak sebagaimana yang tercantum dalam suratgugatan. Pihak-pihak yang berperkara dapat diwakili oleh Kuasa Hukum/Advokat yang ditunjuk melalui surat kuasa. ${ }^{10}$

Apabila para pihak diwakili oleh Kuasa Hukum, Hakim Pemeriksa Perkara meminta Kuasa Hukum untuk menunjukkan Surat Kuasa dan Kartu Tanda Pengenal Advokat sebagai syarat seorang kuasa untuk dapat menjalankan tugas dan fungsinya di persidangan. ${ }^{11}$

Apabila pada hari sidang pertama, salah satu pihak tidak datang, Hakim Pemeriksa Perkara memerintahkan kepada Panitera Pengganti agar pihak yang tidak hadir dipanggil sekali lagi guna memberi kesempatan untuk menghadiri persidangan, maka untuk itu sidang ditunda untuk persidangan yang akan datang dengan menentukan hari/ tanggal persidangan dan kepada pihak yang telah hadir di persidangan diperintahkan untuk hadir tanpa dipanggil lagi dengan panggilan resmi.

\section{Tahap Pra Mediasi}

Apabila pada hari sidang yang telah ditentukan, para pihak baik pihak Penggugat

\footnotetext{
8 Ketentuan Pasal 145 (1) RBG/121 HIR.

9 Wawancara dengan Rony Albas SH, Panitera Muda Perdata Pengadilan Negeri Kelas I B Blitar, 25 Mei 2016.

${ }^{10}$ Ketentuan Pasal 147 RBG.

11 Ketentuan Pasal 3 ayat (2) Undang-Undang No. 18 Tahun 2003 tentang Advokat.
} 
maupun pihak Tergugat sudah lengkap, maka berdasarkan ketentuan Pasal 154 (1) Rbg/ Pasal 130 HIR Jo PERMA Nomor 1 Tahun 2016, sebelum pemeriksaan pokok perkara dimulai, Hakim Pemeriksa Perkara memerintahkan kedua belah pihak yang berperkara wajib menyelesaikan perkaranya secara damai melalui mediasi. Untuk melaksanakan ketentuan Pasal 154 (1) Rbg/ Pasal 130 HIR Jo PERMA Nomor 1 Tahun 2016 tersebut, Hakim Pemeriksa Perkara menerangkan kepada para pihak tentang langkah-langkah yang harus ditempuh oleh kedua belah pihak sehubungan dengan mediasi yang akan dilaksanakan. Sebagai langkah awal, Hakim Pemeriksa Perkara menyarankan kepada para pihak untuk memilih mediator yang akan membantu para pihak dalam proses mediasi.

Kedua belah pihak bebas menentukan mediator sesuai dengan kesepakatan mereka, para pihak berhak memilih seorang atau lebih mediator yang tercatat dalam daftar Mediator. Jika dalam sebuah proses mediasi terdapat lebih dari satu orang mediator maka pembagian tugas mediator ditentukan dan disepakati oleh para mediator. ${ }^{12}$ Apabila para pihak tidak dapat berunding atau sepakat tentang penggunaan mediator baik dari Pengadilan maupun dari luar Pengadilan, paling lama 2 (dua) hari kerja berikutnya maka Hakim Pemeriksa Perkara segera menunjuk Mediator Hakim atau Pegawai Pengadilan. Jika pada pengadilan yang sama tidak terdapat Hakim bukan pemeriksa perkara dan Pegawai Pengadilan yang bersertifikat, Ketua Hakim Pemeriksa Perkara menunjuk salah satu Hakim Pemeriksa Perkara untuk menjalankan fungsi mediator dengan mengutamakan Hakim yang bersertifikat. ${ }^{13}$

Semua perkara perdata gugatan yang telah terdaftar di Pengadilan Negeri Kelas I B Blitar yang melalui mediasi, selalu menggunakan mediator hakim yang ada dalam daftar Pengadilan Negeri Kelas I B Blitar. Belum pernah ada pihak-pihak yang berperkara memilih mediator dari luar Pengadilan Negeri Kelas I B Blitar karena pada dasarnya di wilayah hukum Pengadilan Negeri Kelas I B Blitar belum terdapat mediator non hakim yang bersertifikat atau terakreditasi oleh Mahkamah Agung. ${ }^{14}$ Setelah para pihak sepakat untuk memilih salah satu mediator hakim yang ada dalam daftar Pengadilan Negeri Kelas I B Blitar, maka Hakim Pemeriksa Perkara membuat suatu penetapan tentang penunjukan mediator untuk bertindak sebagai mediator dalam perkara yang sedang ditangani dan guna memberi kesempatan kepada mediator untuk menjalankan tugasnya, setelah tidak ada lagi hal-hal lain yang akan dikemukakan oleh para pihak dalam persidangan hari itu, selanjutnya Hakim Ketua Majelis menutup persidangan dan memberi kesempatan kepada para pihak untuk menempuh mediasi. Pada tahap pra mediasi ini, para pihak menemui mediator yang telah ditunjuk untuk mengadakan kesepakatan tentang jadwal pertemuanpertemuan yang akan diadakan dalam rangka pelaksanaan proses mediasi dan setelah menerima penetapan penunjukan sebagai Mediator selanjutnya Mediator menentukan hari dan tanggal pertemuan mediasi. Dalam hal mediasi dilakukan di gedung Pengadilan, Mediator atas kuasa Hakim Pemeriksa Perkara melalui Panitera melakukan pemanggilan

\footnotetext{
12 Pasal 19 Ayat (1) dan (2) PERMA No.1 Tahun 2016.

13 Pasal 20 PERMA No. 1 Tahun 2016.

14 Wawancara dengan Benhard M.L Toruan S.H. Hakim Mediator bersertifikat pada Pengadilan Negeri Kelas I B Blitar, 25 Mei 2016.
} 
para pihak dengan bantuan juru sita atau juru sita pengganti untuk menghadiri pertemuan Mediasi. ${ }^{15}$

Dalam jangka waktu paling 5 (lima) hari terhitung sejak Hakim Pemeriksa Perkara menerbitkan Penetapan Mediator sebagaimana dimaksud dalam Pasal 20 Ayat (5), para pihak menyerahkan resume perkara kepada pihak lain dan Mediator. ${ }^{16}$ Selanjutnya untuk memberi kesempatan kepada para pihak untuk melengkapi dokumen-dokumen yang diminta oleh mediator, pertemuan ditunda sampai hari dan tanggal yang disepakati bersama dan untuk pertemuan berikutnya akan memasuki tahap mediasi.

\section{Tahap Mediasi}

Setelah menerima berkas perkara dan termasuk dokumen-dokumen yang telah dipersiapkan oleh kedua belah pihak, Hakim Mediator mempelajari apabila ada dokumendokumen berikut bukti-bukti yang turut dilampirkan, kemudian Hakim Mediator pada pertemuan kedua dengan para pihak menawarkan opsi perdamaian dan kepada para pihak dipertanyakan apakah menerima atau menolak opsi tersebut. Tempat pelaksanaan tahap mediasi ini, hampir seluruh perkara di Pengadilan Negeri Kelas I B Blitar memakai tempat di salah satu ruangan yang disediakan oleh Pengadilan Negeri Kelas I B Blitar dan Mediator belum pernah mengadakan pertemuan dengan para pihak dengan menggunakan tempat di luar Pengadilan Negeri Kelas I B Blitar. ${ }^{17}$

Lamanya pertemuan yang diadakan oleh Hakim mediator dengan kedua belah pihak tergantung kepada permasalahan yang akan diselesaikan. Akan tetapi rata-rata memakan waktu antara 15 (lima belas) sampai dengan 30 (tiga puluh) menit setiap kali pertemuan dan pertemuan yang diadakan dapat berlangsung dari 2 (dua) sampai dengan 4 (empat) kali pertemuan. Jarak antara pertemuan pertama dengan pertemuan selanjutnya berjarak 1 (satu) minggu. Ada juga proses mediasi yang hanya berlangsung 1 (satu) kali saja karena masing-masing pihak baik Penggugat maupun Tergugat ngotot atau bersikeras untuk tidak mau berdamai. 18

Waktu proses mediasi di Pengadilan Negeri Kelas I B Blitar, biasanya dilakukan pada pagi hari antara pukul 9.00 WIB sampai dengan pukul 14.00 WIB untuk pertemuan pertama dan untuk pertemuan selanjutnya Hakim mediator menentukan jadwal mediasi yang disepakati oleh para pihak. ${ }^{19}$

Atas persetujuan para pihak dan/atau kuasa hukum, Mediator dapat menghadirkan seorang atau lebih ahli, tokoh masyarakat, tokoh agama atau tokoh adat dan para pihak harus terlebih dahulu mencapai kesepakatan tentang kekuatan mengikat atau tidak mengikat dari penjelasan dan/ atau penilaian ahli dan/ atau tokoh masyarakat. ${ }^{20}$

\section{Akhir Mediasi}

Proses mediasi berakhir apabila dalam waktu yang telah ditentukan mediasi gagal atau apabila mediasi berhasil/mencapai kesepakatan. Mediasi gagal apabila para pihak yang bersangkutan tidak dapat menyelesaikan sengketa diantara mereka secara musyawarah

\footnotetext{
15 Pasal 21 Perma No.1 Tahun 2016.

16 Pasal 24 Ayat (1) dan (2) PERMA No.1 Tahun 2016.

17 Wawancara dengan Suci Astri Pramawati,,SH.M.Hum, Hakim Mediator pada Pengadilan Negeri Blitar, 25 Mei 2016.

18 Ibid.

${ }^{19}$ Ibid.

${ }^{20}$ Ketentuan Pasal 26 PERMA No.1 Tahun 2016.
} 
dalam waktu yang telah ditentukan sesuai dengan PERMA Nomor 1 Tahun 2016 atau atas kewenangan mediator menyatakan mediasi gagal atau tidak berhasil atau tidak dapat dilaksanakan .21

Hal ini berarti persidangan akan dilanjutkan kembali oleh Hakim Pemeriksa Perkara yang menangani perkara tersebut. Mediator memberitahukan secara tertulis kepada Hakim Pemeriksa Perkara untuk menyampaikan bahwa kedua belah pihak dalam perkara tersebut gagal menempuh proses mediasi, dengan demikian Hakim Pemeriksa Perkara segera menerbitkan penetapan untuk melanjutkan kembali perkara sesuai dengan ketentuan hukum acara yang berlaku. 22

Apabila proses mediasi berhasil mencapai kesepakatan, maka Para pihak dengan bantuan mediator wajib merumuskan kesepakatan secara tertulis dalam Kesepakatan Perdamaian yang ditandatangani oleh Para Pihak dan Mediator. Para pihak melalui Mediator dapat mengajukan Kesepakatan Perdamaian kepada Hakim Pemeriksa Perkara agar dikuatkan dalam Akta Perdamaian. Jika Para pihak tidak meghendaki Kesepakatan Perdamaian dikuatkan dalam Akta Perdamaian dan Kesepakatan Perdamaian wajib memuat pencabutan gugatan, selanjutnya Mediator wajib melaporkan secara tertulis keberhasilan Mediasi kepada Hakim Pemeriksa Perkara dengan melampirkan Kesepakatan Perdamaian. Setelah menerima Kesepakatan Perdamaian selanjutnya Hakim Pemeriksa Perkara segera mempelajari dan menelitinya dalam waktu paling lama 2 (dua) hari dan selanjutnya Hakim Pemeriksa Perkara menerbitkan Penetapan hari sidang untuk membacakan Akta Perdamaian. Kesepakatan Perdamaian yang dikuatkan dengan Akta Perdamaian tunduk pada ketentuan keterbukaan informasi di Pengadilan. ${ }^{23}$

\section{Kesepakatan Perdamaian}

Para pihak bebas menuangkan segala apa yang mereka kehendaki menyangkut permasalahan yang ada dalam membuat kesepakatan perdamaian, dalam gugatan sepanjang tidak menyalahi ketentuan perundang-undangan dan dipastikan perjanjian yang mereka buat mengacu kepada ketentuan Pasal 1320 KUH Perdata yaitu adanya :

1. Sepakat mereka yang mengikatkan dirinya.

2. Kecakapan untuk membuat perjanjian.

3. Suatu hal yang tertentu.

4. Suatu sebab yang halal.

Kesepakatan perdamaian yang berisi ketentuan-ketentuan dan kesepakatan kedua belah pihak, dibuat berdasarkan azas kebebasan berkontrak, konsensualisme dan azas iktikad baik. Kebebasan berkontrak, berarti bahwa setiap orang adalah bebas melakukan perjanjian dengan siapa saja mengenai syarat dan bentuk yang ditentukan oleh para pihak, sepanjang tidak ditentukan lain oleh Undang-undang. Azas ini menurut hukum di Indonesia meliputi ruang lingkup sebagai berikut :

1. Kebebasan untuk membuat atau tidak membuat perjanjian.

2. Kebebasan untuk memilih pihak dengan siapa ia ingin membuat perjanjian.

3. Kebebasan untuk menentukan atau memilih klausula dari perjanjian yang akan

\footnotetext{
${ }^{21}$ Ketentuan Pasal 32 Perma No 1 Tahun 2016.

22 Wawancara dengan Benhard M.L. Toruan,SH Hakim Mediator pada Pengadilan Negeri Kelas I B Blitar, 25 Mei 2016.

${ }^{23}$ Ketentuan Pasal 28 Perma No.1 Tahun 2016.
} 
dibuatnya.

4. Kebebasan untuk menentukan obyek Perjanjian.

5. Kebebasan untuk menentukan bentuk suatu Perjanjian.

6. Kebebasan untuk menerima atau menyimpangi ketentuan Undang-Undang yang bersifat opsional.

Azas konsensualisme bahwa perjanjian pada azasnya adalah tidak formil tetapi cukup dengan tercapainya kata sepakat di antara para pihak, perjanjian sejak detik tercapainya kesepakatan. Azas itikad baik adalah terpenuhinya syarat sahnya suatu perjanjian tidak menghilangkan hak dari salah satu pihak untuk membatalkan perjanjian yang dibuat atas iktikad baik. Kesepakatan perdamaian tidak boleh memuat ketentuan-ketentuan sebagai berikut: 24

a. Bertentangan dengan hukum, keterbertiban umum dan/ atau kesusilaan.

b. Merugikan pihak ketiga atau

c. Tidak dapat dilaksanakan.

Kesepakatan perdamaian harus dibuat secara tertulis. Kesepakatan perdamaian ditetapkan berdasarkan suatu formalitas dan bentuk atau tata cara tertentu dinamakan perjanjian formalitas. Dengan demikian, kesepakatan perdamaian adalah merupakan perjanjian formal. Dalam perjanjian formal, kesepakatan atau perjanjian lisan semata-semata antara para pihak yang berjanji belum melahirkan kewajiban kepada pihak yang berjanji untuk menyerahkan sesuatu, melakukan atau berbuat sesuatu. Persyaratan kesepakatan perdamaian harus dibuat secara tertulis merupakan formalitas yang harus dipenuhi agar perjanjian menjadi sah dan mengikat bagi para pihak yang membuat perjanjian tersebut.

Secara umum dapat dikatakan bahwa suatu perjanjian yang dibuat dalam bagaimanapun bentuknya selalu diancam dengan kebatalan atas ketiadaan pemenuhan satu atau lebih ketentuan yang diatur dalam perjanjian tersebut. Keempat syarat sebagaimana tersebut dalam ketentuan Pasal 1320 KUHPerdata, merupakan syarat mutlak yang harus dipenuhi agar suatu perjanjian dapat dianggap sah. Selain daripada itu keabsahan dari tiap perjanjian ditentukan oleh terpenuhi atau tidaknya syarat-syarat yang ditentukan oleh undang-undang. Pada perjanjian formal, harus dipenuhinya suatu formalitas tertentu agar perjanjian yang dibuatnya itu sah adanya. Jika mediasi menghasilkan kesepakatan perdamaian, para pihak dengan bantuan mediator wajib merumuskan kesepakatan secara tertulis dalam Kesepakatan Perdamaian yang ditandatangani oleh para pihak dan mediator. ${ }^{25}$

\section{KEKUATAN HUKUM PERJANJIAN PERDAMAIAN DALAM MEDIASI}

Putusan perdamaian melalui mediasi mempunyai arti yang sangat baik bagi masyarakat pada umumnya dan khususnya bagi orang yang mencari keadilan. Sengketa selesai, penyelesaiannya cepat, biaya ringan dan permusuhan antara kedua belah pihak berkurang dan tidak berkepanjangan.

Berdasarkan ketentuan Pasal 1858 KUHPerdata, segala perdamaian diantara para pihak mempunyai suatu kekuatan seperti suatu putusan Hakim dalam tingkat yang

\footnotetext{
24 Ketentuan Pasal 27 ayat (2) PERMA No.1 Tahun 2016.

${ }^{25}$ Ketentuan Pasal 27 ayat (1) PERMA No. 1 Tahun 2016.
} 
penghabisan. ${ }^{26}$ Apabila perdamaian diantara kedua belah pihak terjadi dalam mediasi, maka dibuatlah Akta Perdamaian dan kedua belah pihak dihukum untuk mentaati isi dari akta perdamaian tersebut.

Akta perdamaian mempunyai kekuatan seperti suatu putusan Hakim yang telah mempunyai hukum tetapmaka terhadap ketentuan perdamaian itu, yang bersangkutan tidak diperkenankan untuk mengajukan banding atau kasasi. Proses selesai sampai disitu dan seandainya suatu waktu diajukan kembali persoalan yang sama oleh salah satu pihak tersebut atau ahli waris dan mereka yang mendapatkan hak daripadanya, maka gugatan terakhir ini akan dinyatakan, dan karenanya gugatan tersebut dinyatakan tidak dapat diterima. ${ }^{27}$ Berbeda dengan perdamaian yang telah berhasil dilakukan oleh kedua belah pihak akan tetapi perdamaian tersebut tidak dikukuhkan melalui putusan Hakim dalam bentuk Akta Perdamaian. Perdamaian semacam itu hanya berkekuatan sebagai persetujuan kedua belah pihak, yang apabila tidak ditaati oleh salah satu pihak, harus diajukan melalui suatu proses Pengadilan. ${ }^{28}$

\section{MEDIATOR DI PENGADILAN NEGERI KELAS I B BLITAR}

Mediator sangat menentukan efektifitas proses penyelesaian sengketa. Ia harus secara layak memenuhi kualifikasi tertentu serta berpengalaman dalam komunikasi dan negosiasi agar mampu mengarahkan para pihak yang bersengketa. Menurut ketentuan Pasal 9 Ayat (1) PERMA Nomor 01 Tahun 2008 yang menyatakan bahwa untuk memudahkan para pihak memilih mediator, Ketua Pengadilan menyediakan daftar mediator sekurang-kurangnya 5 (lima) nama mediator dn disertai dengan latar belakang pendidikan atau pengalaman para mediator yang terdiri dari mediator Hakim dan mediator non Hakim dan Ketua Pengadilan setiap tahun mengevaluasi dan memperbaharui daftar mediator. (Pasal 9 Ayat (6) PERMA Nomor 01 Tahun 2008).

Dengan adanya PERMA Nomor 1 Tahun 2016 tentang Prosedur Mediasi di Pengadilan sebagaimana ketentuan Pasal 13 Ayat (1) yang menyebutkan bahwa setiap mediator wajib memiliki sertifikat mediator yang diperoleh setelah mengikuti dan dinyatakan lulus dalam pelatihan sertifikasi mediator yang diselenggarakan oleh Mahkamah Agung atau lembaga yang telah memperoleh akreditasi dari Mahkamah Agung dan berdasarkan surat Keputusan Ketua Pengadilan, Hakim yang tidak bersertifikat dapat menjalankan fungsi mediator dalam hal tidak ada atau terdapat keterbatasan jumlah mediator bersertifikat (Pasal 13 Ayat (2) PERMA Nomor 1 Tahun 2016).

Dikarenakan untuk wilayah hukum Pengadilan Negeri Kelas I B Blitar tidak adanya mediator non hakim yang bersertifikat maka untuk menjalankan fungsi dan tugas sebagai mediator, dalam hal ini Ketua Pengadilan Negeri Kelas I B Blitar telah menunjuk Hakim Pengadilan Negeri Kelas I B Blitar yang dianggap layak sebagai mediator sebagaimana Surat Keputusan Ketua Pengadilan Negeri Kelas I B Blitar Nomor: W14.U11/125/KP.04.13/01/2016 tanggal 04 Januari 2016.

\footnotetext{
26 Ketentuan Pasal 1858 KUH Perdata.

27 Wawancara dengan Benhard M. L.Toruan,S.H.,.Hakim Mediator bersertifikat pada Pengadilan Negeri Kelas I B Blitar, 25 Mei 2016.

${ }^{28}$ Ibid.
} 
Daftar Mediator Hakim Pengadilan Negeri Kelas I B Blitar

\begin{tabular}{|c|c|c|c|c|}
\hline No & Nama & No. Sertifikat & Profesi & Keterangan \\
\hline 1. & Dr. H. Yapi,S.H.M.H & - & $\begin{array}{l}\text { Hakim/ Ketua } \\
\text { PN. Blitar }\end{array}$ & Mutasi \\
\hline 2. & $\begin{array}{ll}\text { Agung } & \text { Purbantoro, } \\
\text { S.H.M.H } & \end{array}$ & - & $\begin{array}{l}\text { Hakim/ Ketua } \\
\text { PN.Blitar }\end{array}$ & Aktif \\
\hline 3. & Rais Torodji,S.H.M.H & - & $\begin{array}{l}\text { Hakim } \\
\text { PN.Blitar }\end{array}$ & Aktif \\
\hline 4. & $\begin{array}{l}\text { Benhard M.L.Toruan } \\
\text {,S.H. }\end{array}$ & $\begin{array}{l}\text { Nomor: } \\
\text { 110A/KMA/SK/VIII/2008 }\end{array}$ & $\begin{array}{l}\text { Hakim } \\
\text { Blitar }\end{array}$ & Aktif \\
\hline 5. & $\begin{array}{ll}\text { Philip } & \text { Mark } \\
\text { Soentpiet,S.H. } & \\
\end{array}$ & - & $\begin{array}{ll}\text { Hakim } & \text { PN } \\
\text { Blitar } & \\
\end{array}$ & Aktif \\
\hline 6. & Ikrarniekha E, S.H.M.H & - & $\begin{array}{l}\text { Hakim } \\
\text { Blitar }\end{array}$ & Mutasi \\
\hline 7. & Mulyadi Aribowo,SH & - & $\begin{array}{l}\text { Hakim } \\
\text { Blitar }\end{array}$ & Aktif \\
\hline 8. & $\begin{array}{l}\text { Suci Astri P, } \\
\text { SH.M.Hum }\end{array}$ & - & $\begin{array}{ll}\text { Hakim } & \text { PN } \\
\text { Blitar } & \end{array}$ & Aktif \\
\hline
\end{tabular}

Sumber : Data Primer Administrasi Kepaniteraan Pengadilan Negeri Kelas I B Blitar

Sebagaimana ketentuan Pasal 1 PERMA Nomor 1 Tahun 2016 Tentang Prosedur Mediasi Di Pengadilan bahwa Mediator adalah Hakim atau pihak lain yang memiliki sertifikat mediator yang diterbitkan oleh Mahkamah Agung atau lembaga yang telah memperoleh akreditasi dari Mahkamah Agung yang menyatakan bahwa seseorang telah mengikuti dan lulus pelatihan sertifikasi mediasi namun kenyataannya di wilayah hukum Pengadilan Negeri Kelas I B Blitar, mediator hanyalah berasal dari Hakim Pengadilan Negeri Kelas I B Blitar saja baik yang bersertifikat maupun yang belum bersertifikat sedangkan mediator non hakim yang bersertifikat belum ada di wilayah hukum Pengadilan Negeri Kelas I B Blitar sehingga Hakim yang ada di Pengadilan Negeri Kelas I B Blitar mempunyai kewajiban sebagai Mediator untuk menyelesaikan sengketa perdata di Pengadilan Negeri Kelas I B Blitar.

Berdasarkan hal tersebut di atas untuk saat ini, mediator hakim yang terdaftar di Pengadilan Negeri Kelas I B Blitar ada 6 (enam) orang hakim yaitu:

1. Agung Purbantoro, S.H.M.H

2. Rais Torodji, S.H.M.H.

3. Benhard M.L. Toruan, S.H.

4. Philip Mark Soentpiet, S.H.

5. Mulyadi Aribowo, S.H.

6. Suci Astri Pramawati, S.H.M.Hum.

Diantara keenam orang mediator hakim tersebut hanya ada 1 (satu) orang mediator yakni Benhard M.L.Toruan, S.H., yang mempunyai sertifikat yang terakreditasi oleh Mahkamah Agung Republik Indonesia. ${ }^{29}$

Para mediator Hakim ini ditunjuk oleh Ketua Pengadilan Negeri, dan mediator ini berhenti dari jabatan sebagai mediator apabila mediator tersebut pindah tugas atau mutasi

${ }^{29}$ Wawancara dengan Agung Purbantoro, S.H.M.H.Ketua Pengadilan Negeri Kelas I B Blitar, 01 Juni 2016. 
ke Pengadilan Negeri lain atau apabila mediator tersebut tidak dapat menjalankan fungsinya sebagai Hakim atau apabila mediator tersebut telah berakhir masa jabatannya (pensiun). ${ }^{30}$

\section{PERKARA YANG DIPUTUS SECARA MEDIASI DI PENGADILAN NEGERI KELAS I B BLITAR}

Jumlah perkara perdata yang masuk dan terdaftar di Pengadilan Negeri Kelas I B Blitar dari tahun ke tahun adalah bervariasi meskipun dari data yang ada perkara atau gugatan perceraian merupakan perkara yang terbanyak di samping perkara atau gugugatan perbuatan melawan hukum dan perkara atau gugatan wan prestasi, yang mana perinciannya dapat dilihat pada tabel sebagai berikut:

Tabel Perkara Perdata Pengadilan Negeri Kelas I B Blitar Periode Januari 2015-30 Juni 2016

\begin{tabular}{|l|l|l|}
\hline Tahun & $\begin{array}{l}\text { Jumlah Perkara Perdata } \\
\text { gugatan Terdaftar }\end{array}$ & $\begin{array}{l}\text { Jumlah Perkara Perdata gugatan } \\
\text { yang diselesaikan secara Mediasi }\end{array}$ \\
\hline 2015 & $\begin{array}{l}\text { 311 (seratus sebelas) } \\
\text { perkara gugatan. }\end{array}$ & $\begin{array}{l}\text { 3 tiga) Perkara gugatan (Nomor } \\
\text { 12/Pdt.G/2015/PN.Blt, Nomor } \\
87 / \text { Pdt.G/2015/PN.Blt dan Nomor } \\
\text { 96/Pdt.G/2015/PN.Blt) }\end{array}$ \\
& & $\begin{array}{l}\text { 1 (satu) Perkara gugatan (Nomor } \\
\text { 23/Pdt.G/2016/PN.Blt) }\end{array}$ \\
\hline S/d 30 Juni 2016 & 75 (tujuh puluh lima) \\
& perkara gugatan &
\end{tabular}

Sumber : Data Primer Administrasi Kepaniteraan Perdata Pengadilan Negeri Kelas I B Blitar, telah diolah.

Data statistik jumlah perkara perdata gugatan Pengadilan Negeri Kelas I B Blitar yang masuk pada tahun 2015 adalah sebanyak 111 (seratus sebelas) jumlah perkara perdata gugatan yang terdiri dari 70 (tujuh puluh) perkara adalah gugatan perceraian sedangan 41 (empat puluh) perkara adalah gugatan Wanprestasi dan Perbuatan Melawan Hukum.

Terhadap perkara gugatan perceraian sebagian besar tidak dapat dilakukan upaya mediasi dikarenakan pihak Tergugat tidak diketahui keberadaan atau tempat tinggalnya dan Tergugat tidak pernah hadir ke persidangan ataupun mengirimkan wakil atau kuasanya untuk hadir ke persidangan sehingga dikarenakan salah satu pihak tidak hadir ke persidangan dengan demikian penyelesaian gugatan perceraian dengan jalan mediasi tidak dapat dilaksanakan sehingga dilanjutkan dengan pemeriksaan perkara dengan tanpa hadirnya pihak Tergugat atau verstek, sedangkan untuk perkara atau sengketa Perbuatan Melawan Hukum (PMH) dan Wan Prestasi yang mana kedua belah pihak yakni pihak Penggugat dan Tergugat hadir di persidangan, pada persidangan pertama Hakim Pemeriksa perkara mengupayakan kepada kedua belah pihak untuk mengikuti prosedur mediasi sesuai dengan ketentuan PERMA Nomor 1 Tahun 2016, dalam hal ini sepanjang tahun 2015 untuk perkara atau sengketa Perbuatan Melawan Hukum (PMH) dan Wan Prestasi hanya ada 3 (tiga) perkara yang berhasil mencapai kesepakatan damai melalui

${ }^{30}$ Ibid. 
proses mediasi, 4 (empat) perkara gugatan perceraian namun dicabut oleh pihak Penggugat dan ada 3 (tiga) perkara yang gugur atau dicoret dari register perkara. ${ }^{31}$

Tabel Perkara Perdata yang DISELESAIKAN dengan mediasi di Pengadilan Negeri Kelas I B Blitar Tahun 2015

\begin{tabular}{|c|c|c|c|}
\hline No. Register Perkara & Para Pihak & Klasifikasi Perkara & Keterangan \\
\hline $\begin{array}{l}\text { No.12/Pdt.G/2015/PN } \\
\text { Blt }\end{array}$ & $\begin{array}{l}\text { Roesmiati } \\
\text { dkk } \\
\text { Melawan } \\
\text { Petrus } \\
\text { Harijanto }\end{array}$ & $\begin{array}{l}\text { Perbuatan } \\
\text { Melawan Hukum }\end{array}$ & $\begin{array}{l}\text { Mediasi dilaksanakan } \\
\text { dr tanggal } 03 / 03 / 2015 \\
\text { sd tanggal } 24 / 03 / 2015 \\
\text { Akta perdamaian pada } \\
\text { tanggal } 24 / 05 / 2015\end{array}$ \\
\hline $\begin{array}{l}\text { No.87/Pdt.G/2015/PN } \\
\text { Blt }\end{array}$ & $\begin{array}{l}\text { Mambaul } \\
\text { Ulum } \\
\text { Melawan } \\
\text { PT Bank } \\
\text { Pundi Tbk } \\
\end{array}$ & $\begin{array}{l}\text { Perbuatan } \\
\text { Melawan Hukum }\end{array}$ & $\begin{array}{l}\text { Mediasi dilaksanakan } \\
\mathrm{dr} \text { tanggal } 17 / 11 / 2015 \\
\text { sd tanggal } 15 / 12 / 2015 \\
\text { Akta perdamaian pada } \\
\text { tanggal } 15 / 12 / 2015\end{array}$ \\
\hline $\begin{array}{l}\text { No.96/Pdt.G/2015/PN } \\
\text { Blt }\end{array}$ & $\begin{array}{l}\text { Ir. Ezra } \\
\text { Yonathan } \\
\text { dkk } \\
\text { Melawan } \\
\text { PT Ongko } \\
\text { Wijoyo }\end{array}$ & $\begin{array}{l}\text { Perbuatan } \\
\text { Melawan Hukum }\end{array}$ & $\begin{array}{l}\text { Mediasi dilaksanakan } \\
\text { dari tanggal ...2015 s/d } \\
\text { tanggal 19/01/2016 } \\
\text { Akta perdamaian pada } \\
\text { tanggal 21/01/2016 }\end{array}$ \\
\hline
\end{tabular}

Sumber : Data Primer Administrasi Kepaniteraan Perdata Pengadilan Negeri Kelas I B Blitar, telah diolah.

Dari data statistik jumlah perkara perdata gugatan yang masuk pada Pengadilan Negeri Kelas I B Blitar sejak Januari 2016 sampai dengan tanggal 30 Juni 2016 adalah sebanyak 75 (tujuh puluh lima) jumlah perkara perdata gugatan yang terdiri dari 50 (lima puluh) perkara adalah gugatan perceraian sedangan 25 (empat puluh) perkara adalah gugatan Perbuatan Melawan Hukum (PMH) dan Wan prestasi.

Sama halnya dengan tahun 2015 terhadap perkara gugatan perceraian sebagian besar tidak dapat dilakukan upaya mediasi dikarenakan pihak Tergugat tidak diketahui keberadaan atau tempat tinggalnya dan Tergugat tidak pernah hadir ke persidangan ataupun mengirimkan wakil atau kuasanya untuk hadir ke persidangan sehingga dikarenakan salah satu pihak tidak hadir ke persidangan dengan demikian penyelesaian gugatan perceraian tidak dapat dilaksanakan dengan mediasi dan dilanjutkan dengan pemeriksaan perkara dengan tanpa hadirnya pihak Tergugat atau verstek, sedangkan untuk perkara atau sengketa Perbuatan Melawan Hukum (PMH) dan Wan Prestasi yang mana kedua belah pihak yakni pihak Penggugat dan Tergugat hadir di persidangan, pada persidangan pertama Hakim Pemeriksa perkara mengupayakan kepada kedua belah pihak untuk mengikuti prosedur mediasi sesuai dengan ketentuan PERMA Nomor 1 Tahun 2016 dalam hal ini hingga tanggal 30 Juni 2016 untuk perkara atau sengketa Perbuatan Melawan Hukum (PMH) dan Wan Prestasi hanya ada 1 (satu) perkara yang berhasil mencapai

31 Wawancara dengan Benhard M.L.Toruan, S.H. Hakim Mediator bersertifikat pada Pengadilan Negeri Kelas I B Blitar, 14 Juni 2016. 
kesepakatan damai melalui proses mediasi dan ada 2 (dua) perkara gugatan perceraian yang dicabut oleh pihak Penggugat. 32

Tabel Perkara Perdata yang Diselesaikan dengan Mediasi di Pengadilan Negeri Kelas I B Blitar per Tanggal 30 Juni 2016

\begin{tabular}{|l|l|l|ll|}
\hline \multicolumn{1}{|c|}{ No. Register Perkara } & Para Pihak & \multicolumn{1}{|c|}{$\begin{array}{c}\text { Klasifikasi } \\
\text { Perkara }\end{array}$} & \multicolumn{1}{|c|}{ Keterangan } \\
\hline $\begin{array}{l}\text { No.23/Pdt.G/2015/PN } \\
\text { Blt }\end{array}$ & $\begin{array}{l}\text { Suhernowo } \\
\text { dkk }\end{array}$ & $\begin{array}{l}\text { Perbuatan } \\
\text { Melawan }\end{array}$ & $\begin{array}{l}\text { Mediasi dilaksanakan } \\
\text { tanggal 03/03/2015 }\end{array}$ \\
& Melawan sd \\
& Harjito dkk & Hukum & $\begin{array}{lll}\text { Akta perdamaian pada } \\
\text { tanggal 22/03/2016 }\end{array}$ \\
\hline
\end{tabular}

Sumber : Data Primer Administrasi Kepaniteraan Perdata Pengadilan Negeri Kelas I B Blitar, telah diolah.

Dari tabel 5 dan tabel 6 menunjukkan bahwa mediasi belum optimal dapat dilaksanakan sebagai upaya untuk menyelesaikan sengketa perdata di Pengadilan Negeri Blitar.

Ada beberapa faktor yang menyebabkan mediasi tidak dapat terlaksana, yang mana Hakim semestinya melakukan pendekatan psikologis terhadap para pihak yang berperkara dan dengan kemampuan pribadinya seorang hakim mediator berupaya mendamaikan para pihak secara optimal, namun pada prakteknya sangat sulit diimplementasikan mengingat semua keputusan berpulang kembali pada para pihak sedangkan mediator hakim hanya menjembatani jalannya mediasi saja. ${ }^{33}$

Ada 2 (dua) sisi yang menyertai dalam pelaksanaan mediasi di Pengadilan Negeri Kelas I B Blitar, di satu sisi jika mediasi oleh Hakim mediator berhasil mencapai kesepakatan, maka pengurangan perkara yang berlanjut melalui litigasi akan efektif, berarti tujuan mediasi dapat tercapai. Disisi lain pada kenyataannya dengan menempuh mediasi maka akan menambah waktu penyelesaian suatu sengketa perdata. ${ }^{34}$

Mediasi di Pengadilan Negeri Kelas I B Blitar tidak semata-mata formalitas belaka. Hal ini sangat dipengaruhi oleh keaktifan mediator Hakim dalam mengupayakan perdamaian kedua belah pihak meskipun hasil mediasinya dikembalikan lagi pada para pihak dan kuasanya. Ada juga mediator Hakim yang tidak aktif mengupayakan tercapainya target mediasi ini. ${ }^{35}$ Tidak ada alasan hukum untuk mengatakan bahwa pelaksanaan mediasi di Pengadilan merupakan proses yang sifatnya formalitas belaka. Hal ini dikarenakan mediasi merupakan hal yang dilaksanakan. ${ }^{36}$

Tercapainya kesepakatan damai oleh para pihak tidak terlepas dari adanya itikad baik dari para pihak yang berperkara itu sendiri. Jika para pihak mau sedikit menurunkan

\footnotetext{
32 Wawancara dengan Rony Albas, S.H. Panitera Muda Perdata pada Pengadilan Negeri Kelas I B Blitar, 14 Juni 2016.

${ }^{33}$ Wawancara dengan Benhard M.L.Toruan, S.H. Hakim Mediator bersertifikat pada Pengadilan Negeri Kelas I B Blitar, 26 Juni 2016.

${ }^{34} \mathrm{Ibid}$.

${ }^{35} \mathrm{Ibid}$.

${ }^{36}$ Ibid.
} 
egonya, gengsi dan kekerasan hatinya, maka konsensus atau kata sepakat antara kedua belah pihak yang bersengketa dapat dicapai dengan cara mediasi. ${ }^{37}$

Alur penyelesaian sengketa perdata di Pengadilan Negeri Kelas I B Blitar adalah sebagai berikut:

Para Penggugat/ Kuasa hukumnya mendaftarkan surat gugatan ke Pengadilan Negeri Kelasa I B Blitar, setelah surat gugatan Para Penggugat tersebut didaftarkan di Kepaniteraan Perdata Pengadilan Negeri Kelas I B Blitar, selanjutnya Kepaniteraan Perdata melakukan pemeriksaan kelengkapan berkas dan melakukan penghitungan biaya perkara dan biaya panggilan mediasi untuk para pihak selanjutnya pihak Penggugat membayar ongkos/panjar biaya perkara dan setelah membayar ongkos/panjar biaya perkara selanjutnya surat gugatan diberikan nomor register perkara dan selanjutnya bagian Kepaniteraan Perdata Pengadilan Negeri Kelas I B Blitar menyerahkan surat gugatan yang sudah diberikan nomor register perkara tersebut kepada Ketua Pengadilan Negeri dan selanjutnya Ketua Pengadilan Negeri menunjuk Majelis Hakim Pemeriksa Perkara dan membuat penetapan tentang Penunjukan Majelis Hakim Pemeriksa Perkaraselanjutnya oleh bagian Kepaniteraan Perdata berkas perkara yang sudah ditetapkan Majelis Hakim Pemeriksa perkara tersebut diserahkan kepada Panitera Pengadilan Negeri untuk ditetapkan Panitera Pengganti dan Jurusita/ JurusitaPengganti selanjutnya berkas perkara diserahkan kepada Ketua Majelis Hakim Pemeriksa Perkara untuk ditetapkan jadwal persidangan dan selanjutnya berkas perkara diserahkan kepada Panitera Pengganti untuk disampaikan kepada Jurusita/ Jurusita Pengganti guna melakukan pemanggilan kepada para pihak untuk hadir pada persidangan Pengadilan Negeri Kelas I Blitar.

Selanjutnya pada hari persidangan pertama, setelah kedua belah pihak yakni Penggugat dan Tergugat hadir di persidangan selanjutnya Hakim Pemeriksa Perkara mewajibkan para pihak untuk menempuh upaya perdamaian melalui mediasi yang dibantu oleh seorang Mediator dan dikarenakan wilayah hukum Pengadilan Negeri Kelas I B Blitar tidak mempunyai mediator non hakim bersertifat yang terakreditasi oleh Mahkamah Agung Republik Indonesia sehingga untuk melakukan mediasi terhadap para pihak, Hakim Pemeriksa Perkara setelah berunding terlebih dahulu kepada kedua belah pihak mengenai mediator hakim selanjutnya menunjuk Hakim Pengadilan Negeri Kelas I B Blitar yang bertugas sebagai Mediator yang mempunyai sertifikat Mediator dan selanjutnya Ketua Majelis Hakim Pemeriksa Perkara menetapkan nama mediator Hakim bersertifikat yakni Benhard M. L. Toruan, S.H. berdasarkan Penetapan Penunjukan Mediator tertanggal 03 Maret 2015 untuk menangani proses mediasi paling lama 40 (empat puluh) hari kerja terhitung sejak tanggal penetapan penunjukan mediator tersebut hingga adanya laporan mediator kepada Hakim Pemeriksa perkara tentang berhasil atau tidaknya mediasi tersebut.

Selanjutnya berdasarkan penetapan penunjukan mediator tersebut dan setelah bertemu dengan para pihak selanjutnya mediator menentukan jadwal pertemuan mediasi dan

${ }^{37} \mathrm{Ibid}$. 
mewajibkan para pihak yakni prinsipal untuk hadir sebagaimana jadwal atau agenda mediasi yang telah disepakati antara mediator dengan kedua belah pihak.

Setelah mediator melakukan beberapa kali pertemuan mediasi dengan para pihak yakni terhitung sejak tanggal 03 Maret 2015 hingga tanggal 24 Maret 2015 akhirnya proses mediasi telah mencapai kesepakatan damai sebagaimana dituangkan dalam surat pernyataan perdamaian tertanggal 24 Maret 2016 yang ditandatangani oleh kedua belah pihak.

Berdasarkan laporan hakim mediator dan permohonan kedua belah pihak perihal kesepakatan perdamaian selanjutnya pada tanggal 24 Maret 2015 Hakim Pemeriksa Perkara yang mengadili sengketa atau perkara antara kedua belah pihak telah menjatuhkan putusan sebagai berikut:

1. Menghukum Para Penggugat dan Tergugat untuk mentaati dan melaksanakan Kesepakatan Perdamaian yang telah dibuat dan disetujui bersama.

2. Membebankan biaya yang timbul dalam perkara ini kepada pihak Penggugat sebesar Rp. 261.000,- (dua ratus enam puluh satu ribu rupiah).

Dengan adanya akta perdamaian di atas maka perkara atau sengketa antara kedua belah pihak dinyatakan telah selesai dan tidak perlu dilanjutkan ke proses persidangan. Dengan kata lain proses mediasi yang dilakukan oleh Mediator Hakim di Pengadilan Negeri Kelas I B Blitar telah berhasil mencapai kesepakatan dengan dibuatnya kesepakatan perdamaian oleh para pihak dan setelah putusan akta perdamaian tersebut dibacakan dalam persidangan yang terbuka untuk umum dan dihadapan kedua belah pihak selanjutnya Hakim Pemeriksa Perkara menyampaikan kepada para pihak untuk mentaati Akta Perdamaian tersebut.

Pada saat mewawancarai kuasa hukum pihak Para Penggugat yang menangani perkara tersebut yang mengatakan bahwa sebelum perkara atau sengketa tersebut didaftarkan di kepaniteraan Pengadilan Negeri Blitar, Para Penggugat telah mengupayakan agar diselesaikan secara pribadi dan kekeluargaan mengenai permasalahan yang tengah dihadapi antara para pihak namun tidak membuahkan hasil atau tidak menemukan jalan keluar karena masing-masing para pihak saa itu berkeras mempertahankan prinsip atau kepentingannya masing-masing.

Dikarenakan persoalan antara kedua belah pihak tidak menemukan titik terang akhirnya sengketa antara kedua belah pihak tersebut dibawa ke ranah hukum dengan memasukkan gugatan perdata ke Pengadilan Negeri Kelas I B Blitar. ${ }^{38}$

Terhadap sengketa atau perkara para pihak tersebut Hakim Mediator telah melaksanakan tugas dan fungsinya selaku mediator dengan berusaha semaksimal mungkin untuk dapat mendamaikan kedua belah pihak yang bersengketa yang notabene masih merupakan keluarga. Setelah melakukan pendekatan secara emosional dan dengan memberikan pemahaman tentang baik atau tidaknya perkara tersebut dilanjutkan dengan segala konsekuensinya dan berusaha atau bekerjasama mencari berbagai penyelesaian yang terbaik bagi para pihak hingga akhirnya kedua belah pihak dapat menurunkan egoisme dan kekerasan hatinya masing-masing sehingga tercapai win-win solution antara kedua belah pihak dan selanjutnya itikad baik antara kedua belah pihak tersebut akan dituangkan

38 Wawancara dengan Moh. Syaeroji, SH. Sebagai Kuasa Hukum Penggugat dalam Perkara No. 12/Pdt.G/2015/PN.Blt, 01 Juni 2015. 
dalam satu kesepakatan perdamaian dan selanjutnya mediator dan kedua belah pihak membuat dan merumuskan kesepakatan perdamaian dengan dasar kerelaan hati untuk mau berdamai dengan para pihak.

Setelah para pihak membuat dan menandatangani kesepakatan perdamaian dengan keiklasan dan kerelaan hatinya dan tanpa ada paksaan dan arahan dari siapapun juga selanjutnya mediator menyampaikan itikad baik dan kesepakatan perdamaian para pihak tersebut kepada Hakim Pemeriksa perkara dan selanjutnya berdasarkan kesepakatan perdamaian tersebut, Hakim Pemeriksa Perkara mengeluarkan putusan yang isinya mewajibkan kepada para pihak untuk mentatai dan melaksanakan kesepakatan perdamain yang telah dibuat dan disetujui bersama tersebut.

Meskipun ketentuan PERMA Nomor 01 Tahun 2008 Jo PERMA Nomor 1 Tahun 2016 yang mewajibkan kepada para pihak untuk melakukan mediasi sebagai upaya untuk menyelesaikan perkara perdata namun kenyataannya apabila dilihat dari hasil penyelesaian perkara perdata di Pengadilan Negeri Kelas I B Blitar, maka penyelesaian sengeketa perdata dengan jalan mediasi masih dirasakan kurang maksimal. ${ }^{39}$

Pelaksanaan mediasi kadang kala hanya sebatas formalitas, hal ini disebabkan mediatornya tidak sungguh-sungguh bertujuan untuk mendamaikan para pihak. Hakim, misalnya tidak bersemangat untuk menyelesaikan perkara melalui mediasi. Apalagi dalam PERMA Nomor 1 Tahun 2008 Jo PERMA Nomor 1 Tahun 2016 disebutkan bahwa mediator hakim tidak dibayar atau tidak mendapat honor untuk pekerjaannya sebagai mediator, otomatis hal ini berdampak pula pada kinerja Hakim dalam menjalankan fungsi dan tugasnya sebagai mediator. 40

Yang menjadi penyebab sering gagalnya atau tidak berhasilnya mediasi adalah pendekatan yang digunakan oleh mediator hanya sebatas pendekatan hukum. Proses mediasi hendaklah dilakukan dengan pendekatan hati, itikad baik dan dengan mengedepankan hati nurani. Agar proses mediasi dapat berjalan dengan lancar dan hasil yang diharapkan dapat tercapai maka diperlukan keterlibatan para pihak untuk melepas kepentingan dan egoisme sehingga tercapai win-win solution bagi para pihak. ${ }^{41}$

Mediasi diupayakan untuk tetap dilakukan di pengadilan meskipun keberhasilannya dianggap masih kurang maksimal namun demikian masih lebih baik daripada tidak ada sama sekali, dikarenakan meskipun jumlah perkara yang berhasil diselesaikan lewat mediasi masih minim tetapi mediasi tetap sangat berarti untuk mengurangi penumpukan perkara di pengadilan. ${ }^{42}$

\section{FAKTOR-FAKTOR YANG MEMPENGARUHI PELAKSANAAN MEDIASI DI PENGADILAN NEGERI KELAS I BLITAR}

Keberhasilan mediasi di Pengadilan selain didukung oleh itikad baik dari para pihak, juga memerlukan suatu kekuatan agar proses penyelesaian perkara boleh berjalan sesuai

\footnotetext{
${ }^{39}$ I bid.

40 Wawancara dengan Suci Astri P, SH.M.Hum. sebagai mediator di Pengadilan Negeri Kelas I B Blitar, 25 Mei 2016.

41 Wawancara dengan Moh. Syaeroji,S.H. sebagai Kuasa Hukum Penggugat pada perkara perdata No.12/Pdt.G/2015/PN.Blt,25 Mei 2016.

42 Ibid.
} 
dengan apa yang diharapkan. Mediasi merupakan salah satu bentuk alternatif penyelesaian sengketa yang memiliki kekuatan sehingga mediasi menjadi salah satu pilihan yang dapat dipakai oleh mereka yang sedang bersengketa.

Christopher W. Moore mengemukakan padangannya mengenai kekutatandalam mediasi yaitu:

"If the poweror influence potencialsof theparties arewell developed, fairly equal instrength, andrecognizedbyall disputants, the mediator'sjobwillbethe assistthe disputants inusingtheir influenceeffectively to produce mutually satisfactoryresults".

"Jika potensi pengaruh kekuatan dari pihak-pihak dikembangkan dengan baik, persamaan yang fair dalam kekuatan tersebut dan disadari oleh pihak bersengketa, tugas mediator untuk mengakses pengaruh salah satu pihak ke pihak lain secara efektif akan menghasilkan keputusan/ kepuasan bersama para pihak." ${ }^{\prime 10}$

Kekuatan adalah faktor kunci dalam berunding/ bermediasi. Keberhasilan mediasi ditentukan bukan karena belas kasihan, akan tetapi karena para pihak saling membutuhkan satu sama lain agar sengketa yang diperdebatkan boleh terselesaikan dengan baik. Kebutuhan para pihak satu dengan yang lainnya tergantung pada ada tidaknya kekuatan masing-masing dari para pihak. Untuk itulah perlu dibangun suatu kekuatan sebagai upaya memperkuat posisi dalam mediasi.

Mediasi memiliki suatu kekuatan untuk memberikan kewenangan bagi para pihak dalam menyelesaikan sengketa sesuai dengan apa yang menjadi keinginan mereka. Para pihak mengontrol jalannya proses mediasi dan dapat menentukan cara-cara yang lebih serderhana, jika dibandingkan dengan proses beracara formal di pengadilan. Kemudian para pihak wajib mematuhi keputusan yang telah disepakati bersama dengan bantuan mediator. ${ }^{43}$

Mediator bertindak sebagai penengah yang sifatnya netral atau tidak berpihak pada kedua belah pihak dengan tujuan mendapatkan penyelesaian yang adil dan tidak merugikan salah atu pihak. Pelaksanaan mediasi dilaksanakan secara tertutup atau rahasia. Hal ini menjadi ciri khas daripada mediasi itu sendiri sehingga banyak kalangan tertentu yang sedang menghadapi suatu perkara tidak menginginkan perkaranya diumumkan atau dimuat di media massa. Kerahasiaan akan membantu para pihak membangun kepercayaan dengan mediator. Di sisi lain mediator harus berusaha untuk menjaga kerahasiaan dari substansi mediasi itu sendiri, serta sebaiknya menghancurkan seluruh dokumen di akhir sesi mediasi yang telah dibuat sebelumnya. Para pihak diharapkan dapat saling menghormati kerahasiaan tersebut. Dengan ini para pihak dapat mengungkapkan masalahnya secara langsung dan terbuka. Hal ini penting untuk menemukan kebutuhan dan kepentingan mereka secara nyata.

Pada prinsipnya informasi yang dikemukakan selama berlangsungnya proses mediasi, mendapat perlindungan hukum untuk tidak dikemukakan pada proses yang lain atau pihak

${ }^{43}$ I Made Sukadana, Mediasi Peradilan,PrestasiPustaka, Jakarta:2012, hal.194 
ketiga. Menurut Pasal 35 Ayat (3) PERMA Nomor 1 Tahun 2016, menyebutkan bahwa "jika para pihak tidak berhasil mencapai kesepakatan, pernyataan dan pengakuan para pihak dalam proses mediasi tidak dapat digunakan sebagai alat bukti dalam proses persidangan perkara". Hal ini mempunyai tujuan yaitu agar proses mediasi tidak disalahgunakan oleh para pihak yang tidak beritikad baik untuk menjebak lawan dengan berdalih ingin berdamai, padahal mereka memiliki tujuan yang tidak baik. Selain itu, hal ini dilakukan dengan tujuan agar para pihak tanpa rasa takut dapat mengungkapkan fakta di dalam proses mediasi.

Para pihak yang bersengketa lewat jalur mediasi dapat membahas berbagai aspek atau sudut pandang dari sengketa yang sedang dihadapi, tidak hanya tertujuk kepada aspek hukum tetapi dapat juga aspek-aspek lainnya. Mediasi bersifat konsensual dan kolaboratif, sehingga hasil yang akan didapatkan yaitu menang- menang (win-win solution) bagi para pihak.

Dilihat dari sifatnya yang konsensual atau mufakat dan kolaboratif, mediasi selalu menghasilkan penyelesaian sengketa dengan cara menang-menang bagi para pihak (win-win solution), sehingga tidak merugikan para pihak yang berperkara. Mediasi termasuk di dalam salah satu alternatif penyelesaian sengketa yang relatif murah dan tidak memakan waktu yang cukup lama jika dibandingkan dengan berperkara melalui proses litigasi. Disamping itu hasil yang didapat selama menempuh proses mediasi yaitu kesepakatan bersama oleh para pihak, sehingga para pihak yang bersengketa tidak mengajukan keberatan atas apa yang telah disepakati.

Penyelesaian sengketa tidak diserahkan kepada kemauan dan kehendak hakim atau mediator, tetapi diselesaikan oleh para pihak sendiri sesuai dengan kemauan mereka, karena merekalah yang lebih tahu hal yang sebenarnya atau sesungguhnya atas sengketa yang dipermasalahkan. ${ }^{44}$

Mengenai kinerja penegak hukum, Mardjono Reksodiputro menulis, rasa hormat masyarakat terhadap sistem peradilan sangat bergantung pada sistem pelayanan peradilan. Saat ini masyarakat sangat tidak puas terhadap pelayanan peradilan. Pengadilan dianggap gagal memenuhi harapan sebagai "benteng terakhir" melawan ketidak adilan. ${ }^{45}$

Hal ini melahirkan rasa kurang hormat terhadap sistem peradilan, dan keluarnya tuduhan bahwa peradilan telah dipolitisasi dan korup. Dalam hal korupnya pengadilan, praktisi hukum (pengacara dan jaksa) juga dipersalahkan karena turut memfasilitasi terjadinya penyuapan. ${ }^{46}$

Khususnya pengacara dan konsultan hukum dituduh sebagai perantara dalam transaksi yang menjadikan "hukum sebagai komunitas dagang". Mutu hakim juga mendapat sorotan tajam, banyak hakim dianggap tidak memiliki pengetahuan yang memadai atas hukum substantif dan hukum acara. ${ }^{47}$

Adapun faktor-faktor yang mempengaruhi pelaksanaan mediasi di Pengadilan Negeri Kelas I B Blitar berdasarkan hasil penelitian yang dilakukan adalah sebagai berikut:

a. Dari pihak hakim (mediator hakim), antara lain:

${ }^{44}$ Ibid.

${ }^{45}$ Satjipto Raharjo, Op.Cit, hal. 111

${ }^{46}$ Ibid.

${ }^{47} \mathrm{Ibid}$. 
1. Hakim mediator belum memahami teori/tehnik yang berkaitan dengan mediasi sehingga dalam pelaksanaannya tidak maksimal. Sebagaimana diketahui dari hasil penelusuran berkas perkara perdata di Pengadilan Negeri Kelas I B Blitar mayoritas pelaksanaan mediasi tidak berhasil mencapai kesepakatan. ${ }^{48}$

2. Tergantung kepada masing-masing mediatornya yakni aktif atau tidaknya mediator dalam mediasi. Ada yang berkomitmen terhadap tujuan adanya mediasi yaitu dengan mengurangi penumpukan perkara dan ada yang merasa dibebani dengan adanya prosedur mediasi ini yaitu menambah beban kerja mediator itu sendiri. ${ }^{49}$

b. Dari Pihak Advokat atau Kuasa Hukum para pihak, antara lain:

1. Advokat berpikiran bahwa proses mediasi tidak membawa keuntungan bagi dirinya karena apabila mediasi mencapai kata sepakat maka tugasnya sebagai advokat atau kuasa hukum pihak akan berhenti atau selesai sehingga berakibat pada penghasilan atau honor yang diterimanya selaku kuasa hukum yang ditunjuk oleh para pihak.

2. Advokat kurang serius atau kurang mendukung kliennya untuk mengikuti proses mediasi. ${ }^{50}$

3. Advokat beranggapan dulunya telah diadakan upaya somasi kepada para pihak sehingga hanya buang-buang waktu saja kalau diterapkan lagi upaya perdamaian.

c. Dari Para Pihak (prinsipal), antara lain:

1. Kurangnya niat dan itikad baik para pihak untuk mau berdamai melalui mediasi di pengadilan. ${ }^{51}$

2. Para pihak sering tidak hadir pada waktu proses mediasi berlangsung sehingga tidak mendukung proses mediasi. ${ }^{52}$

3. Para pihak menganggap mediasi di pengadilan hanya sebagai alasan untuk memperlambat penyelesaian perkaranya saja. ${ }^{3}$

4. Para pihak sama-sama berkeras ingin menempuh jalur litigasi dengan kata lain tidak ingin berdamai lagi. ${ }^{54}$

48 Wawancara dengan Benhard M.L. Toruan, S.H., Hakim Mediator bersertifikat pada Pengadilan Negeri Kelas I B Blitar, 02 Juni 2016.

${ }^{49}$ Wawancara dengan Suci Astri Pramawati, SH.M.Hum., Hakim Mediator pada Pengadilan Negeri Kelas I B Blitar, 02 Juni 2016.

50 Wawancara dengan Moh.Syaeroji, SH .Kuasa Hukum Penggugat Perkara Perdata No. 12/Pdt.G/2015/PN Blt, 25 Mei 2016.

${ }^{51} \mathrm{Ibid}$.

52Ibid.

${ }^{53}$ Ibid.

${ }^{54} \mathrm{Ibid}$. 


\section{PENUTUP}

Penerapan PERMA Nomor 1 Tahun 2016 tentang Prosedur Mediasi Dalam Penanganan Perkara Perdata Di Pengadilan Negeri Kelas I B Blitar seoptimal mungkin diupayakan berjalan sesuai dengan ketentuan, namun hasilnya sangat tergantung kepada para pihak itu sendiri. Dalam hal ini secara garis besar prosedur mediasi tetap dijalankan sesuai ketentuan PERMA Nomor 1 Tahun 2016, masalah berhasil atau tidaknya mencapai perdamaian tidak bisa dipaksakan dalam mencapainya.

Perkara yang berhasil mencapai perdamaian melalui mediasi di Pengadilan Negeri Kelas I B Blitar masih sangat minim karena sebagian besar perkara dilanjutkan ke proses sidang berikutnya. Hal ini tidak lepas dari itikad baik para pihak yang biasanya datang ke pengadilan ketika perkaranya sudah tidak bisa diselesaikan lagi. Adanya daftar nama hakim sebagai hakim mediator dari Pengadilan Negeri Kelas I B Blitar sesuai dengan Surat Keputusan Ketua Pengadilan Negeri Kelas I B Blitar namun hakim tersebut tidak pernah mengikuti sertifikasi mediator yang dilaksanakan oleh Mahkamah Agung. Minimnya hakim mediator dari kalangan hakim Pengadilan Negeri Kelas I B Blitar yang mempunyai sertifikat dari Mahkamah Agung dengan adanya fakta bahwa hanya 1 (satu) orang hakim dari daftar mediator dari kalangan hakim Pengadilan Negeri Kelas I B Blitar yang telah mempunyai sertifikat mediator yang terakreditasi Mahkamah Agung.

Faktor-faktor yang mempengaruhi pelaksanaan mediasi di Pengadilan Negeri Kelas I B Blitar bisa dilihat dari faktor struktur hukum, substansi hukum dan budaya hukum. Dari faktor struktur hukum, sangat diperlukan itikad mediator baik hakim maupun non hakim, dan kemauan untuk berdamai dari para pihak. Dari faktor substansi hukum terdapat kesulitan tersendiri dalam mengakses informasi mengenai penyelenggaraan sertifikasi mediator, belum jelasnya kriteria keberhasilan suatu mediasi, dan ketidakjelasan mengenai insentif hakim dan non hakim yang berhasil menjalankan fungsinya sebagai mediator. Adapun dari faktor budaya hukum para pihak yang berperkara masih terfokus pada upaya hukum melalui jalur litigasi sehingga mediasi yang dilaksanakan seringkali tidak membuahkan hasil yaitu tercapainya perdamaian di antara para pihak yang bersengketa. 


\section{DAFTAR PUSTAKA}

Buku:

Abbas, Syahrial, Mediasi dalam Hukum Syariah, Hukum Adat dan Hukum Nasional, Kencana Jakarta, 2011.

Amriani, Nurnaningsih S.H., M.H., Mediasi Alternatif Penyelesaian Sengketa Perdata di Pengadilan, Cet Kedua, Jakarta : PT Raja Grafindo Persada , 2012, hal 9.

Arwan, Firdaus Muhammad, Cara Mudah Memahami Dan Melaksanakan PERMA No. 1 Tahun 2008Tentang Prosedur Mediasi Di Pengadilan, Pusdiklat MARI, 2010.

Atmasasmita, Romli, Reformasi Hukum, Haka Azasi Manusis Dan Penegakan Hukum, Bandung: Mandar Maju, 2001.

Black, Henry Campbell, Black's Law Dictionary Contennial Edition, St Paul Minn: West Publishing Co., 1991.

Budiarjo, Ali, Reformasi Hukum Di Indonesia, Jakarta: Cyberconsult, 2000.

Dewi, D.S., Implementasi PERMA No. 1 Tahun 2008 Tentang Prosedur Mediasi Di Pengadilan, Makalah, Bogor: Pusdiklat MARI, 2010.

Friedman, Lawrence, The Legal System,New York: Russel Sage Foundation, 1975.

Goodpaster, Garry, Tinjauan Terhadap Penyelesaian Sengketa, Seri Dasar-Dasar Hukum Ekonomi 2 Arbitrase di Indonesia, Jakarta: Ghalia Indonesia, 2005.

Goodpaster, Gary, Panduan Negosiasi Dan Mediasi, Edisi Pertama, Jakarta : Proyek ELIPS, 1999.

Hadikusuma, Hilman, Pengantar Ilmu Hukum Adat Indonesia, Bandung: CV Mandar Maju, 1992.

Hamzah, Andi Penegakan Hukum Lingkungan, Jakarta: Sinar Grafika, 2005.

Harahap, M.Yahya, Hukum Acara Perdata , Jakarta : Sinar Grafika, 2007.

Harahap, M.Yahya, Ruang Lingkup Permasalahan Dan Eksekusi Bidang Perdata, Jakarta: Gramedia, 1995.

Kamil, Ahmad dan M. Fauzan, Kearah Pembaruan Hukum Acara Perdata Dalam SEMA Dan PERMA, Cet. I Jakarta : Kencana Predana Media Group, 2008.

Margono, Suyud, ADR dan Atbitrase, Proses Pelembagaan dan aspek Hukum, Jakarta: Ghalia Indonesia, 2000.

MARI, Pedoman Pelaksanaan Tugas Dan Administrasi Pengadilan, Jakarta: Buku II, 1994.

Marzuki, Peter Mahmud, Penelitian Hukum, Jakarta : Kencana, 2008.

Muhammad, Abdul Kadir, Hukum Acara Perdata Indonesia,Cet. III, Bandung : Alumni. 1996.

Perwataatmaja, Karnaen, Bank dan Auransi Islam di Indonesia, Jakarta: Prenada Media, 2005.

Pusdiklat Teknis Peradilan, Materi Pelatihan Mediasi, Mahkamah Agung RI, 2010.

R.Soesilo, RBG/HIR Dengan Penjelasannya, Bogor : Politea 1985.

Raharjo, Satjipto, Wajah Hukum Di Era Reformasi, Kumpulan Karya Ilmiah Menyambut 70 Tahun Prof Satjipto Rahardjo, Bandung : Citra Aditya Bakti , 2000.

Santaja, Atja, Perkembangan Mediasi Di Berbagai Negara, Pusdiklat MARI, 2010.

Soeharto, H., Mediasi dan Perdamaian, Mahkamah Agung RI, 2002.

Soekanto, Soerjono, Sosiologi Hukum Dalam Masyarakat , Jakarta : Rajawali Press , 1987.

Soekanto, Soerjono, Wawancara sebagai salah satu teknik dalam penelitian bertujuan untuk mengumpulkan keterangan atau data, Ringkasan Metodologi Penelitian Hukum Empiris, Jakarta: Indhilco, 1990.

Subekti, Prof, KUHPerdata dengan tambahan UU Pokok Agraria dan UU Perkawinan, Jakarta: Pradnya Paramita, 1992.

Sukadana, I Made, Mediasi Peradilan, Jakarta: PrestasiPustaka, 2012.

Sunarmi, Penemuan Hukum, Medan, USU, 2009.

Sutiyoso, Bambang, Hukum Arbitrase dan Alternatif Penyelesaian Sengketa, Gama Media, 
Yogyakarta, 2008.

Tim Penyusun Depdiknas, Kamus Besar Bahasa Indonesia, Jakarta : Balai Pustaka, 2007.

Widjaja, Gunawan, Alternatif Penyelesaian Sengketa, Jakarta: Raja Grafindo Press, 2001.

\section{Peraturan perundang-undangan:}

Undang-Undang No. 30 Tahun 1999 tentang Arbitrase dan Alternatif Penyelesaian Sengketa Undang-Undang No. 48 Tahun 2009 tentang Kekuasaan Kehakiman

Undang-Undang No. 18 Tahun 2003 tentang Advokat

Kitab Undang-Undang Hukum Perdata

Peraturan Mahkamah Agung No. 2 Tahun 2003

Peraturan Mahkamah Agung No.1 Tahun 2008

Peraturan Mahkamah Agung No.1 Tahun 2016 